for Lodgings. The Committee will think it right to pay regard to œconomy, as well as convenience, in these arrangements." Without doubt the present local committee shares this aspiration; but members will not fail to take cognisance of a footnote to the above announcement, which appears in the
Report for 1831: "On Tuesday a public dinner was provided at Twelve Shillings a Ticket; on the other days, during the session, ordinaries at from Five to Seven Shillings a head : venison, game, and fruit being contributed...." In this respect at least there need be no fear that history will repeat itself.

\title{
Obituary
}

\section{Guillaume Bigourdan}

THE death of M. Bigourdan has taken from us a veteran astronomer, well known to many of his English colleagues. He attended the meeting of the Paris Academy of Sciences on Feb. 22, in his usual health, but died suddenly on Feb. 28 . Born at Sistels (Tarn-et-Garonne) on April 6, 1851, M. Bigourdan graduated in the École d'Astronomie in Paris, and was in 1877 appointed by M. Tisserand as an assistant in the Observatory at Toulouse. Here he was employed on meridian astronomy and devoted his leisure to historical studies in astronomy, which interested him all his life.

In 1879, M. Bigourdan was appointed assistant at the Paris Observatory and had charge of the large equatorial. Here he spent many years in the most assiduous observations of the positions of nebulæ and clusters. In this very trying work he determined the positions of the known nebulæ with all the precision possible from visual observations, discovered many new ones, and incidentally made measures of comets and double stars. The intention underlying these arduous observations was to provide such accurate positions of the nebulæ that future astronomers might detect small movements in these very distant objects. The results were published in the Annales of the Paris Observatory, and have since been collected in five large volumes, consisting of about three thousand pages. The gold medal of the Royal Astronomical Society was awarded to M. Bigourdan in 1919 for this monumental work.

Owing to differences between French and English observers in the values for the longitude of Paris, a re-determination was made in 1902 by M. Bigourdan and M. Lancelin working simultaneously with Sir Frank Dyson and Mr. Hollis. The results were in satisfactory accordance, and the mean differs by only $0.01^{8}$ from the recent determination made by ' wireless' transmission of time-signals. M. Bigourdan was from its commencement interested in the transmission of time by wireless, which is due to so great an extent to the initiative of General Ferrié. When Paris became the centre of the international time service, he was, until 1928, director of the Bureau.

In 1882, M. Bigourdan took part in the observations of the transit of Venus in Martinique, and he was a member of eclipse expeditions to Senegal in 1892 , to Spain in 1900 , and to Tunis in 1905 . He was for many years a member of the Bureau des Longitudes, and enriched many volumes of the Annuaire by articles on astronomical topics. His most important work on the history of astronomy was the bringing out of the "Annales célestes du dix-septième siècle" by $A$. G. Pingré. This work was completed in manuscript in 1791 and a beginning made of its publication. This went on slowly until the death of Pingré and then ceased. The manuscript was lost, but was found by $\mathrm{M}$. Bigourdan under a wrong designation in the Paris Observatory. It was printed in 1901 under the auspices of the Academy of Sciences.

M. Bigourdan was courteous and affable, and always put his point of view with vigour and vivacity. An incident which took place at the meeting of the International Astronomical Union at Rome in 1922 may be recalled. The discussion was bilingual. One of the British delegates spoke in French, which his British colleagues all understood. Whether M. Bigourdan had not been listening, or whether he wished maliciously to indicate that the French was not perfect, I do not know, but he amused his British colleagues by calling out "Traduction".

$\mathrm{He}$ married a daughter of Admiral Mouchez, and they had nine children, to whom we would offer our respectful sympathy. F. W. Dyson.

\section{News and Views}

\section{Oliver Heaviside's Work}

Ат a meeting of the Institution of Electrical Engineers on April 21, Dr. W. E. Sumpner gave the annual Kelvin Lecture, choosing as his subject the work of Oliver Heaviside. Before the lecture, the Faraday medal, the highest honour the Institution can give, was presented to Sir Oliver Lodge. Dr. Sumpner said that the work of Heaviside blended telegraphy, the earliest activity of electrical engineers, with radio communication, their latest activity. The older electricians were in the habit of applying Kelvin's formulæ, which apply only to submarine cables, to telephony. Heaviside's idea of increasing the self- induction of the line was diametrically opposed to the prevailing practice. The whole industry was in the hands of a government department very properly reluctant to try expensive experiments. Heaviside's mathematics were not easy to understand and wanted laborious study even by professed mathematicians. This was why some of his theories, although suggested several years before they were practically tried in France and America, were never actually put to the test in Great Britain. His 'distortionless' circuit enabled signals to be transmitted at high speed in submarine cables and made telephony through long cables possible. His work on the cable problem did

No. 3261, VoL. 129] 
a great deal more than lead to the theory of the 'loading coil'. It showed that ordinary telegraphy was only a special form of directed wave telegraphy. Heaviside was the first radio-telegraphist. His analysis of Maxwell's theory was of the orthodox type, but when he dealt with the cable problem, he threw over all the conventional methods used by mathematicians.

\section{The Mellon Institute at Pittsburgh}

ThE nineteenth Annual Report of the director, Dr. E. R. Weidlein, to the trustees of Mellon Institute of Industrial Research, Pittsburgh, Pa., with which the name of Mr. Andrew Mellon, the new U.S. Ambassador in London, is associated, has recently been issued. It appears that the sum of 722,541 dollars was received by the institution from industrial fellowship donors during the fiscal year ended Feb. 29,1932 , bringing the total for the past 21 years to $8,277,018$ dollars. Throughout the past year 75 industrial fellowships, employing 176 scientific workers and engineers, were in operation. At the close of the year, 58 fellowships were active, and of these, 28 have been at work for five years or longer and 13 have concluded more than ten years of research. Since 1911, when the industrial fellowship system was established at the University of Pittsburgh, Mellon Institute has had fellowships on 230 distinct subjects, on which 775 workers have been engaged, and 313 fellows and 357 fellowship assistants, having completed their services, have entered the fields of industry and education. As trained additions to the forces of manufacturing and teaching, these men constitute the Institute's greatest contribution to humanity. The constructional work on the Institute's new building is proceeding satisfactorily; it is thought that this edifice will be completed and ready for occupancy in the summer of 1933.

\section{Testing Work for the Building Industry}

IN recent years there has been a growing demand on the Building Research Station of the Department of Scientific and Industrial Research for tests and reports on building materials and forms of construction. In order to enable the Station to cope with these requests, a panel of approved testing laboratories is being established to act in association with the Station. The essence of the scheme is to put the Station in the position to have tests carried out at laboratories on the panel and then to incorporate the results in Government reports or certificates issued by the Station. The bulk of the tests will probably be mechanical or physical ; of the chemical tests, most will probably be simple analyses. Applications are invited from testing laboratories wishing to participate in the scheme. Further particulars and forms of application can be obtained from the Director, Building Research Station, Garston, Herts.

\section{Building Research}

WE have received the Report of the Building Research Board for the year 1930 (London: H.M. Stationery Office, 2s. $6 d$. net), which is a document of 136 pages with an index. The report deals with a number of important aspects of building materials and construction. In a section on damp walls it is pointed out that it does not seem possible to guarantee that a solid brick or masonry wall will exclude damp under all conditions, but no instance has been recorded of the failure of a properly constructed cavity wall to exclude damp. Experiments on noise in buildings showed that where the weight of material necessary to obtain sound insulation is excessive, a considerable reduction of noise can be obtained by the use of composite structures with air spaces between the component parts. The efflorescences on brickwork, due to soluble salts in the bricks, mortar, or external sources, are best removed by washing by hand when the amount of soluble salts is limited. The preparation of standard specifications for building materials is receiving special attention by the Board in conjunction with the British Standards Institution, and it is highly satisfactory to note that a considerable measure of co-operation between the Building $\mathrm{Re}$ search Station and industry has been achieved. The report also refers to a considerable amount of work on concrete and reinforced concrete which has been carried out, and a new laboratory is being erected to house this work. The report shows that a very useful purpose is being fulfilled by the Board, the activities of which may be expected to increase in several directions as time goes on.

\section{Agricultural Parasites Research in Canada}

INTERNAL parasites are one of the stock-farmer's biggest problems all over the British Empire. They are the poultry-farmer's worst enemy, and, in all probability, constitute the most severe check on the growth of the poultry industry in the British Isles. In Canada it has been estimated that parasitic infestation causes an annual loss of $£ 4,000,000$ and is responsible for the death of one-tenth of the Dominion's live stock. A new Empire centre for the scientific study of internal parasites has been established in Canada, with the assistance of a grant from the Empire Marketing Board. New buildings, which will house the Institute of Parasitology, are now being erected by the Quebec Government at Macdonald College, the agricultural college attached to McGill University. The scheme is being financed for three years jointly by the Empire Marketing Board and the National Research Council of Canada. It marks the first occasion on which the Canadian Government and the Empire Marketing Board have combined to support a joint scheme of research. It is hoped that the new Institute may eventually become an Empire headquarters for the study of internal parasites, somewhat as Onderstepoort, in South Africa, has become recognised as an Empire centre for animal diseases research. The scheme therefore provides a fresh example of Empire team-work in the field of agricultural research.

\section{Change-Over from Direct to Alternating Current}

Aт the present time electricians are interested in the problem of the change-over from direct current to alternating current systems of supply. Where new systems are being laid down in Great Britain the

No. 3261, VoL. 129] 